\title{
Viral carcinogenesis: virus implicated in cancer
}

\author{
Luisa Lina Villa, ${ }^{1,2}$ \\ From São Paulo Advanced School of Comparative Oncology \\ Águas de São Pedro, Brazil. 30 September - 6 October 2012
}

The first consistent observations that viruses could be associated with some types of cancer where made almost a century ago. A great deal of effort was involved in unraveling the molecular mechanism underlying carcinogenesis implicated to animal and human viruses. As a result of these studies, a strong link between some viral agents and several human cancers has been established. Some viruses as the Epstein-Barr virus (EBV), hepatitis B virus (HBV), hepatitis $\mathrm{C}$ virus $(\mathrm{HCV})$, human $\mathrm{T}$-cell lymphotropic virus type I (HTLV-I), immunodeficienciy virus type I (HIV-1) and several human papillomavirus types (including types $16,18,31,33,35,39,45,51,52,56,58,59$ and 66) have been classified as group 1 carcinogens by the International Agency for Research in Cancer (IARC). Infection by these viruses constitutes a heavy burden for human populations as it accounts for almost $15 \%$ of all human malignancies. Furthermore, many other viral agents have been classified as probably (group 2A carcinogens) or possibly (group 2B carcinogens) carcinogenic to humans and others have been occasionally found in human tumors suggesting that this figure is just an underestimation of viral involvement in human cancer etiology. Nevertheless, viral infection appears as one of the main cancer risk factors that could be prevented. Prevention and control of infection by these agents could dramatically reduce the incidence of some prevalent cancers and, consequently, have a great impact on public health.

\section{Competing interests}

There are no competing interests in this presentation.

\section{Author details}

${ }^{1}$ Dept of Radiology and Basic Oncology, School of Medicine, USP, São Paulo, Brazil. ${ }^{2} \mathrm{HPV}$ Institute, Santa Casa de São Paulo, São Paulo, Brazil.

Published: 4 April 2013

\footnotetext{
Correspondence: luisapvilla@gmail.com

'Dept of Radiology and Basic Oncology, School of Medicine, USP, São Paulo, Brazil

Full list of author information is available at the end of the article
}

doi:10.1186/1753-6561-7-S2-K11

Cite this article as: Villa: Viral carcinogenesis: virus implicated in cancer.

BMC Proceedings 2013 7(Suppl 2):K11.
Submit your next manuscript to BioMed Central and take full advantage of:

- Convenient online submission

- Thorough peer review

- No space constraints or color figure charges

- Immediate publication on acceptance

- Inclusion in PubMed, CAS, Scopus and Google Scholar

- Research which is freely available for redistribution

Submit your manuscript at www.biomedcentral.com/submit

\section{() Biomed Central}

C Biomed Central

๑ 2013 Villa; licensee BioMed Central Ltd. This is an Open Access article distributed under the terms of the Creative Commons Attribution License (http://creativecommons.org/licenses/by/2.0), which permits unrestricted use, distribution, and reproduction in any medium, provided the original work is properly cited. 